\title{
Teacher learning in collaborative curriculum design
}

\author{
Citation for published version (APA):
}

Voogt, J., Westbroek, H., Handelzalts, A., Walraven, A., McKenney, S., Pieters, J., \& De Vries, B. (2011). Teacher learning in collaborative curriculum design. Teaching and Teacher Education, 27(8), 1235-1244. https://doi.org/10.1016/j.tate.2011.07.003

DOI:

10.1016/j.tate.2011.07.003

Document status and date:

Published: 01/11/2011

Document Version:

Peer reviewed version

Document license:

CC BY-SA

Please check the document version of this publication:

- A submitted manuscript is the version of the article upon submission and before peer-review. There can be important differences between the submitted version and the official published version of record. People interested in the research are advised to contact the author for the final version of the publication, or visit the DOI to the publisher's website.

- The final author version and the galley proof are versions of the publication after peer review.

- The final published version features the final layout of the paper including the volume, issue and page numbers.

Link to publication

\section{General rights}

Copyright and moral rights for the publications made accessible in the public portal are retained by the authors and/or other copyright owners and it is a condition of accessing publications that users recognise and abide by the legal requirements associated with these rights.

- Users may download and print one copy of any publication from the public portal for the purpose of private study or research.

- You may not further distribute the material or use it for any profit-making activity or commercial gain

- You may freely distribute the URL identifying the publication in the public portal.

If the publication is distributed under the terms of Article 25fa of the Dutch Copyright Act, indicated by the "Taverne" license above, please follow below link for the End User Agreement:

https://www.ou.nl/taverne-agreement

Take down policy

If you believe that this document breaches copyright please contact us at:

pure-support@ou.nl

providing details and we will investigate your claim.

Downloaded from https://research.ou.nl/ on date: 26 Apr. 2023 
Elsevier Editorial System(tm) for Teaching and Teacher Education

Manuscript Draft

Manuscript Number: TATE-D-10-00728R2

Title: Teacher learning in collaborative curriculum design

Article Type: Research Paper

Keywords: Teacher, Teacher learning, Professional development, Collaborative curriculum design, Curriculum innovation

Corresponding Author: Dr Joke Voogt, PhD

Corresponding Author's Institution: University of Twente

First Author: Joke Voogt, PhD

Order of Authors: Joke Voogt, PhD; Hanna Westbroek, PhD; Adam Handelzalts, PhD; Amber Walraven, PhD; Susan McKenney, PhD; Jules Pieters, PhD; Bregje De Vries, PhD

Abstract: The Interconnected Model of Professional Growth (Clarke \& Hollingsworth, 2002) was used to identify processes of teacher learning during the collaborative design of curriculum materials in the context of curriculum innovation. Nine published studies from six different countries about teachers' collaborative curriculum design were analyzed to identify the learning processes that collaborative curriculum design fosters. It was concluded that the Interconnected Model of Professional Growth, although initially developed to recognize learning processes in individual teachers, can also be used to identify learning processes that are fostered by collaborative curriculum design in teams of teachers. 


\title{
Teacher learning in collaborative curriculum design
}

\author{
J. Voogt \\ j.m.voogt@utwente.nl \\ University of Twente, Department of Curriculum Design and Educational Innovation \\ P.O.Box, 217, 7500AE Enschede, the Netherlands \\ H. Westbroek \\ h.b.westbroek@utwente.nl \\ University of Twente, Department of Curriculum Design and Educational Innovation \\ P.O.Box, 217, 7500AE Enschede, the Netherlands \\ A. Handelzalts \\ a.handelzalts@utwente.nl \\ University of Twente, Department of Curriculum Design and Educational Innovation \\ P.O.Box, 217, 7500AE Enschede, the Netherlands
}

\author{
A. Walraven \\ a.walraven@utwente.nl \\ University of Twente, \\ Department of Curriculum Design and Educational Innovation \\ P.O.Box, 217, 7500AE Enschede, the Netherlands
}

\author{
S. McKenney \\ s.e.mckenney@utwente.nl \\ University of Twente, Department of Curriculum Design and Educational Innovation \\ P.O.Box, 217, 7500AE Enschede, the Netherlands \\ J. Pieters \\ j.m.pieters@utwente.nl \\ University of Twente, Department of Curriculum Design and Educational Innovation \\ P.O.Box, 217, 7500AE Enschede, the Netherlands \\ B. de Vries \\ bregje.devries@han.nl \\ HAN University of Applied Sciences, Faculty of Education \\ P.O.Box 30011, 6503 HN Nijmegen, the Netherlands
}

Corresponding Author: J. Voogt, University of Twente, Department of Curriculum Design and Educational Innovation, P.O.Box, 217, 7500AE Enschede, the Netherlands. Email j.m.voogt@utwente.nl; Phone +31534893559 Fax: +31534893759 


\section{Research highlights (max 85 characters incl spaces):}

- Teachers increased their PCK and self-confidence by participating in a TDT.

- To improve student learning, curriculum implementation should be part of a TDT

- Active involvement in TDTs helped teachers to change their beliefs

- Learning processes in TDTs could be identified with the Interconnected Model of

Professional Growth 


\section{Teacher learning in collaborative curriculum design}

\section{Introduction}

Developments in the learning sciences (Bransford, Brown, \& Cocking, 2000) show how student learning benefits when it is situated in meaningful contexts, when students are actively engaged in their own learning process, and when they collaborate with others (e.g. Cobb, 1994; Greeno, 1998). Recently, researchers in the field of teacher professional development (Putnam \& Borko, 2000; Borko, 2004; Little, 2002; Parke \& Coble, 1997) have emphasized the similarities of these findings for teacher learning and began to study the implications for teacher professional development arrangements. Putnam \& Borko (2000) for instance argue that teacher learning needs to be situated in authentic contexts which are meaningful to teachers' practice, that it is social in nature and therefore needs to be situated in social contexts, and that it is distributed. In describing the distributed nature of teacher learning, Putnam and Borko (p.10) discuss how intelligent activities, such as teaching, need to benefit from distributed knowledge, available across persons who bring in their own expertise. Teacher learning from this perspective acknowledges that learning is not limited to formal professional development, but takes place in all the arenas in which the teacher participates: the classroom, the community of teachers, and the school environment (Borko, 2004). Formal professional arrangements are challenged to make use of these different arenas when they provide opportunities for teachers to learn. Research on teacher professional development arrangements aiming to improve or change classroom practice, that aligns with these views on teacher learning, emphasize 
that teacher professional development needs to: (a) focus on a deeper understanding of subject matter and on guiding students' thinking about subject matter (Borko, 2004; Whitcomb, Borko, Liston, 2009; Garet et al., 2001; Penuel, Fishman, Yamaguchi, \& Gallagher, 2007); (b) provide examples of concrete classroom applications of the general ideas underlying the change (Elmore \& Burney, 1999; Davis \& Krajcik, 2005, Van den Akker, 1988, Voogt, 2010); (c) expose teachers to actual practice rather than providing them with descriptions of practice (Elmore \& Burney, 1999; Penuel et al., 2007 Garet et al, 2001); (d) provide opportunities for collaboration with peers and experts in attuning the practice to the local context (Borko, 2004; Ball \& Cohen, 1996; Elmore \& Burney, 1999; Penuel et al., 2007, Garet et al, 2001, Simmie, 2007); (e) involve follow up support (Elmore \& Burney, 1999; Joyce \& Showers, 1995; Penuel et al. 2007; Garet et al, 2001); (f) be coherent with teachers' own professional development goals and the goals for their student learning (Penuel et al, 2007; Garet et al., 2001); and (g) be stretched over time (Penuel et al, 2007; Garet et al., 2001).

One way to comply with these features of effective teacher professional development is to involve teachers in collaborative (re-)design of curriculum materials (Handelzalts, 2009; Simmie, 2007; Voogt, 2010). A curriculum is a plan for learning (Taba, 1962). Curriculum materials are the products of a curriculum. They are developed for several curriculum levels (national, e.g. standards; school, e.g. the school curriculum plan; or classroom, e.g. lessons, modules activities). Teachers' collaborative (re-)design usually focuses on student activities, lesson, modules, and courses. In collaborative (re-)design, teachers create new or adapt existing curriculum materials in collaboration with each other, and often with experts such as educational design experts, educational researchers, 
and domain experts. The process of (re-)design provides opportunities for teachers to reflect on the curriculum starting from their personal knowledge and beliefs, their practice, and their goals for student learning (Parke \& Coble, 1997). The interaction with other teachers and experts may deepen and challenge their reflections (Borko, 2004). Because (re-)designing curriculum results in concrete artifacts - curriculum materials teachers are not only exposed to the new practice, but actively shape their own practice. Participation in well-scaffolded collaborative curriculum design processes therefore has the potential to contribute to the professional development of the teachers involved (Borko, 2004; Ball \& Cohen, 1996; Parke \& Coble, 1997) and to the production of materials which are valid and feasible in view of both teaching practice and the intended curriculum (Loucks-Horsley, Hewson, Love, \& Stiles, 1998; Penuel, Fishman, Yamaguchi, \& Gallagher, 2007; Ben-Peretz, 1990; Clandinin \& Connelly, 1992). Although it is assumed that the activities teachers undertake during (re-)design of curriculum materials can be beneficial, most studies on teacher collaborative curriculum design tend to only focus on measuring effects of collaborative design on teacher learning and on the implementation of the curriculum. They hardly examine the processes in collaborative design that promote teacher learning: the interaction with peers, facilitators and external stimuli, the experimentation in classroom practice, and the factors in the environment that hinder or facilitate teachers' collaborative design.

The study presented here was undertaken to gain more insight into the processes of collaborative design in teacher designs teams (TDTs) that foster teacher learning and development. In this study, TDTs were defined as teams of at least two teachers who 
collaboratively design or (re)-design curriculum materials, with the aim of improving or changing their own instructional practice (Handelzalts, 2009). The Interconnected Model of Professional Growth (Clarke \& Hollingsworth, 2002) was used for analyzing the processes of collaborative design in TDTs. To study learning and development processes in TDTs, high-quality, peer-reviewed studies found through a systematic literature search were analyzed. See the methods section for a detailed description of how these studies were selected.

\section{Studying processes of teacher learning}

To study how TDTs provide opportunities for teachers to learn, understanding is needed about the outcomes which may be expected from teacher professional development arrangements. Usually, outcomes from teacher professional development are described in terms of change. Changes are expected in knowledge and skills, beliefs and attitudes, classroom practice and/or student experiences. Researchers generally agree that teacher professional development ultimately should lead to improved student learning (Guskey, 2000; Cochran-Smith, 2005; Parke \& Coble, 1997; Clarke \& Hollingsworth, 2002). However, the relationship between student learning and the other outcomes is complicated, often reciprocal, and not very clear (Guskey, 1986). To underline that the changes in teachers are deeply rooted in teacher's classroom experiences, Guskey (1986, 2000) proposed a linear relationship in which teacher learning of new knowledge and skills influences classroom practice, and classroom practice influences student learning. 
Beliefs and attitudes according to Guskey (1986) only change after experiencing the effects on student learning. Guskey's view (2000) is interesting in that he takes into account the fact that effects of professional development may not visibly result in changed classroom practice, because the environment does not always support classroom implementation of the newly learned knowledge and skills. Contrary to the linear model Guskey proposed, Clarke and Hollingsworth (2002) developed the Interconnected Model of Professional Growth (see Figure 1) which allows for individual paths in teacher development. In their model, Clarke and Hollingsworth (2002) explicate the underlying processes that mediate teacher change. Because we are interested in the processes through which TDTs encourage teacher learning, we chose to use the Clarke and Hollingsworth (2002) model for our study.

---Insert Figure 1 about here----

Clarke and Hollingsworth (2002) identify four domains in which change can take place: the personal domain, the domain of practice, the domain of consequences, and the external domain. The personal domain constitutes teacher knowledge, skills, attitudes and beliefs. Change in this domain happens when teachers acquire new knowledge, skills, attitudes or beliefs. The domain of practice refers to all forms of professional experimentation. Although Clarke and Hollingsworth (2002) note that the domain of practice is often limited to teachers' experience in the classroom, they explicitly mention 
that teachers' professional experimentation is not limited to the classroom only. Teachers participate in different professional arenas in which they learn: the teacher community, the school environment, their professional associations, etc. As teacher design activities can be considered an inherent part of the teaching profession, we therefore see these activities as belonging to the domain of practice. Change in this domain occurs when teachers develop new curriculum materials and try out new practices. The domain of consequences deals with the outcomes of new practices for the teachers themselves and their students. Change in this domain occurs when teachers perceive these outcomes as salient. The three domains form a part of the teacher's professional life. We will call them 'teacher-related domains'. One domain is outside the professional day-to-day world of the teacher. This is the external domain. This domain offers the teacher sources of information and/or stimuli and support to develop new practices. Change in this domain is defined as becoming acquainted with new ideas, practices and/or strategies, introduced and developed by others. Change may occur in any domain, and is mediated through the processes of enactment and reflection. Reflection refers to teachers' thinking about their practice ('reflection on action') and during practice ('reflection in action') (Schön, 1987). Enactment refers to teachers' role as curriculum developer who, according to Snyder, Bolin and Zumwalt (1992, p. 418), "grows ever more competent in constructing positive educational experiences." The interaction that takes place in the TDTs with peers, experts, support materials or classroom practice, is essentially enactment and reflection. According to Clarke and Hollingsworth (2002), the processes of enactment and reflection can be described in terms of paths connecting the various domains, which mirror the learning processes taking place. The model of Clarke and Hollingsworth (2002) allows 
teachers participating in the same professional development initiative to follow different paths in their learning processes. The model neither prescribes the changes that may occur as a result of a professional development initiative, nor the paths - the reflection and enactment processes - that mediate the change. To characterize teacher professional development, Clarke and Hollingsworth (2002) distinguish among change sequences and growth networks. A change sequence consists of "...two or more domains together with the reflective or enactive links connecting these domains; where empirical data support both the occurrence of change and their causal connection” (p. 958). They typically consist of teachers discussing and experimenting with the stimuli offered through professional development initiatives. Change sequences are the learning and development processes fostered by the professional development initiatives. Change sequences may result in teacher change as the immediate short term outcome of the professional development initiative. In our study, teacher change reflects the immediate outcomes of teacher participation in a TDT. A growth network is a change sequence resulting in longlasting change (as supported by the data) in any of the three 'teacher-related domains' (the personal domain, the domain of practice, and/or the domain of consequences). According to Clarke and Hollingsworth (2002), long-lasting change, which they call professional growth, is more relevant than the short term changes that usually occur due to a professional development intervention.

This study has been set out to better understand the teacher learning that takes place in TDTs during collaborative design activities and during classroom implementation of the design. Nine peer-reviewed articles about TDTs in six different countries form the basis 
for this study. These articles were found through a systematic literature search (see the methods section and Author et al, under review). We used the Interconnected Model of Professional Growth to analyze how the teacher design teams presented in these articles provide opportunities for teachers to embark on change processes which are likely to contribute to teacher change or to teacher professional growth. The overall research question that guided the study was: 'Which changes in each of the domains of the Interconnected Model of Professional Growth were observed in teachers during the TDT intervention?

Four sub questions were formulated to answer the overall research question:

1. Which changes in teachers (in terms of the Interconnected Model of Professional Growth) were observed during collaborative curriculum design and classroom implementation respectively?

2. Which change sequences, mediated by reflection or enactment processes, were encouraged during the TDT intervention?

3. Did participation in the TDT contribute to long-lasting change (teacher professional growth)?

4. Which factors in the environment influenced the TDT intervention?

The final sub-question is not directly related to the Interconnected Model of Professional Growth, but was added to examine environmental factors that hindered or facilitated the work in TDTs and hence might have influenced teacher learning.

\section{Methods}




\subsection{Search for and selection of the studies}

The articles selected for this study were the result of a systematic search of the literature about Teacher Design Teams. To select the articles only high-quality, peer-reviewed articles that were published between 1988 - 2009 were examined. The search was based on a combination of three (groups) of terms: (a) 'teacher'; (b) 'curriculum design/ development/ evaluation/ innovation/ reform/ analysis/ implementation or material development or teacher developed materials or teaching materials or lesson materials'; and (c) 'different synonyms of collaboration/ cooperation/ team/ participation/ collegial/ network/ co-construction'. Only articles written in the English language were included in the study. Initial systematic searches in major databases Scopus, Web of Science and Eric yielded 492 articles.

To be included the studies had to meet the following criteria:

- Collaboration: activities described involve cooperation of at least two teachers.

- Design process: The collaborative team activities that are described cover (part of) a design cycle: problem analysis or definition, design of curriculum products, implementation of the products in practice, and evaluation/ reflection on the products and redesign. If only the summative evaluation of learner activities was reported, the article did not meet this inclusion criterion.

- Curricular product: The collaboration contributes to the realization of a curricular product, e.g. national syllabi, lesson plans, modules, and learning materials.

- Empirical evidence: The article reports on the collection and interpretation of data. Articles that are of a theoretical nature were excluded. 
The abstracts were screened to examine whether they met the inclusion criteria. Based on this abstract-screening, 319 articles were labeled as negative and 173 as maybe positive / positive. Next, the full text articles $(n=173)$ were screened. The articles were distributed among three teams of two researchers. The level of agreement between researchers was substantial (Cohen's kappa resp. 0.68 and 0.77 ) to quite strong (0.86). After individual screening, differences in judgment were discussed until agreement was reached. Based on the full text screening, another 144 articles were labeled as negative and 29 as positive. Most articles that were rejected turned out to be of a more theoretical nature rather than empirical. Additionally, a substantial amount of articles did not provide any information on design processes but concerned only summative evaluations of learning activities. Next, the articles were judged on the specific quality criteria of (a) consistency; and (b) appropriate measurements to secure validity (see also Author et al., under review). Based on these criteria, each article was labeled independently by two researchers as having 'sufficient' or 'insufficient' quality. Differences in outcomes between researchers were discussed until consensus was reached. Sixteen articles were considered 'insufficient' and were therefore excluded from the review. Thirteen articles were considered sufficient. Nine articles concerned in-service teachers and formed the basis for this study. The other articles concerned pre-service teachers and were therefore excluded from this study. These nine studies are briefly summarized in Table 1 in terms of their design task, the main focus of the study, the team composition, the duration of the TDT and the instruments used for data collection. 
---Insert Table 1about here----

\subsection{Analysis}

A case study approach (Yin, 2003) was used to analyze the articles. Each article was considered a case. The empirical data reflected in the findings section of each study was considered the unit of analysis. All nine studies applied qualitative methods.

The analysis of the nine articles occurred in three stages. In the first stage, the first author carefully read each article to get a better understanding of the studies in relation to the Interconnected Model of Professional Growth. Based on this reading and with the research questions in mind the codes were initially developed by the first author. Then the first author started to code the findings sections of each article. While coding the first articles, the codes still needed fine-tuning to clarify their meaning. This meant that the first author went back and forth between the articles and the coding until the codes and their meaning were finalized. The final codes and their meaning are presented in Appendix A together with an example of each code. The first author coded the findings sections of all nine studies and summarized the codes of each study in a separate document. The length of the coded segments differed a lot between and within the articles. In some articles findings were summarized, while in other articles interactions in the teams or journal entries were presented verbatim. The summaries were organized according to the research questions and were about two pages per study and helped to give an overall picture of each study. Two examples showing how original codes were summarized are presented below.

\section{$\underline{\text { Example } 1}$}




\section{Original coding}

Whereas initially the ideas for student activities originated mainly from previous practice, used resources identified in thus far unfamiliar books or materials available at the workshop as references (EN-EXTPRAC). At a later stage teams were confident (CH-PERS) enough to search the library or the internet, or specify data required from organizations such as the meteorological services, the lands and survey department, the water authority, or the nutrition council (EN-PERS-EXT) (George \& Lubben, 2002, p. 668).

\section{Summary}

Teachers first used sources for student activities provided to them through the workshop (EN-EXT-PRAC), but after a while they extended the external domain in looking for other sources than those provided by the national syllabus or the materials from the facilitator (EN-PERS-EXT). This change happened because of the self-confidence gained through their participation in the TDT (CH-PERS).

\section{Example 2}

\section{Original coding}

David shared the tool (CWR-Critical Web Reader) [with the team] (EN-PERS-EXT). This initial version of the tool engendered discussion and disagreement about the way students read Web sites as sources of information as David's journal entry, composed after a team meeting just two days later highlights: "How do students read sources of information...”.The CWR lays out a fairly linear process, but we talked about different ways of reading and that is always an iterative, clinical process. Huge discussions, actually debate, centered on the steps students/we take in reading texts.... [the discussion is summarized]....( RE-EXTPERS). We agreed that it is an iterative process that does not necessary lend itself to the linear formalized process that the CWR takes them through'. At the end of this meeting, Wanda, one of the social studies teachers on the team, offered to refine the CWR to prepare it for student use (EN-PERS-PRAC). These revisions resulted in the team dividing the initial version of the CWR in two parts (CH-PRAC).

\section{Summary}


Teachers studied (EN-PERS-EXT) the Critical Web Reader (a tool to guide research) and this triggered a discussion about the linear process of research suggested in the Critical Web Reader and how they and their students are reading and processing texts (RE-EXT-PERS). This discussion resulted in one of the team members offering to refine the Critical Web Reader to prepare it for student use (EN-PERS-PRAC). Her changes were then adopted by the team (CH-PRAC).

In the second stage, the second author was involved. She was familiar with the articles before taking part in the analysis of the articles for this study. In order to check the summaries made by the first author, she first made herself familiar with the Interconnected Model of Professional Growth. Then the first author and the second author discussed the codes and their meaning, based on examples of the coding done by the first author. After that the second author read all articles again and critically checked the summary documents for consistency and completeness with the original article. Only minor differences between the first and second author were found and were discussed.

In the third stage the first author used the Interconnected Model of Professional Growth as an analytical framework for the cross-article analysis. The summaries of each study were used to find change sequences, environmental factors influencing the TDTs, and indications of professional growth across the articles. The change sequences factors and indications of professional growth that were found and how to interpret these in terms of the Interconnected Model of Professional Growth were discussed among the authors of the paper. The results of the cross-article analysis are presented in the findings.

There were two difficulties in using the Interconnected Model of Professional Growth in this study. First, the model is mainly focused on describing the development of individual 
teachers. This was not possible in the present study, because we used published articles that tried to find overarching patterns, more so than individual changes. While some articles reported individual changes through quotes or observations, these data were used to illustrate overarching patterns that the authors observed. Our approach therefore seems to some extent opposed to the affordances of the Interconnected Model of Professional Growth as proposed by Clarke and Hollingsworth (2002). But when the aim is to understand how TDTs promote enactment and reflection in ways that effectively promote teacher professional development, we considered the use of this model the most valuable. Second, not all studies of TDTs aimed at getting a better understanding of teacher professional development. In some articles, the main focus was on curriculum development or curriculum implementation. Yet, in analyzing each article, we found that many notions relating to teacher professional development were made. Nonetheless, we realize that the contribution of TDTs to teacher professional development might be more than elicited in those articles not explicitly focusing on teacher professional development.

\section{Findings}

\subsection{Enactment and reflection processes resulting in changes in domains}

Changes in the personal domain, the domain of practice or the domain of consequences (the 'teacher-related domains') are considered by Clarke and Hollingsworth (2002) as 
indicators of teacher change. Although changes in the external domain may also happen, they are not considered indications of teacher change. Change sequences mediated by reflection and enactment processes, may occur between the four domains. The changes we found, and particularly the processes of reflection and enactment underlying these changes, provide evidence on how the TDTs that were analyzed for this study contribute to teacher learning.

The design process can be characterized by several stages: problem analysis, design and development, implementation and evaluation (Gustafson \& Branch, 1997). All articles reported about the design and development activities of the TDT, which were often preceded by activities related to problem analysis. Not all studies reported about the implementation of the design by the TDT. Evaluation activities were reported related to the design and/or implementation of the curriculum materials. In this study, we distinguish between two major phases related to the design process. The design phase includes activities related to problem analysis, design and development, and evaluation of the design. The implementation phase includes activities related to implementation and evaluation of the implementation. An overview of the changes we found in the four domains (as distinguished by Clarke and Hollingsworth), as well as the design and/or implementation phases in which these changes occurred, is presented in Table 2. Based on our analysis, a detailed description of these changes, is given below. We first report our findings about the observed changes in TDTs and the underlying reflection and enactment processes during design, followed by findings observed during implementation. 
---Insert Table 2 about here----

\subsection{Domain changes and change sequences during curriculum design}

During the design phase, teachers are involved in curriculum design which, according to Clarke and Hollingsworth (2002), can be considered an area of professional experimentation. From this perspective, teacher design activities resulting in curriculum materials belong to the domain of practice. Our analysis showed changes in the external domain, the personal domain and the domain of practice during the curriculum design activities. It was not always possible to trace the change sequences that caused the changes that were reported. We therefore limit the description of our findings to those which show the change sequences underlying the change.

In seven of the nine studies (not in Fernandez, 2005; Schneider \& Pickett, 2006) the TDTs were coordinated by an external facilitator, who guided the team, led discussions, and provided study materials and other resources. A first step in some of the TDTs was to define the problem the TDT wanted to tackle and to fully understand the design task: problem analysis. Teachers were asked to study and to reflect on the external materials provided to them. These materials consisted of professional readings (Rock \& Wilson, 2005; Fernandez, 2005), exemplary and existing curriculum materials (George \& Lubben, 2002; Fernandez, 2005; Voogt et al., 2005; Parchmann et al., 2006; Baildon \& Damico, 2008; Shkedi, 1996; Fernandez, 2005; Deketelaere \& Kelchtermans, 1996)) or 
syllabi (George \& Lubben, 2002). Teachers discussed and analyzed these materials with their perceptions of student thinking in mind. This helped them to better define the design task. In three studies (George \& Lubben, 2002; Voogt et al., 2005; Parchmann et al., 2006), teachers received specific training as part of the TDT. In two of these studies, teachers were also supported by a web environment to communicate within (Voogt et al., 2005) and between teams (Parchmann et al., 2006). Particularly the (exemplary) curriculum materials were perceived by the teachers as essential tools in supporting the reflection and enactment processes in the TDTs Voogt et al. (2005), Parchmann et al. (2006), Baildon and Damico (2008), George and Lubben, 2002). In their study of a large scale curriculum reform effort in chemistry teaching, Parchmann et al. (2006) concluded that studying and adapting the exemplary materials in the TDTs appeared very effective in realizing the changed curriculum.

Although the external domain is, by definition, characterized by the input of ideas, practices and/or strategies of others into the learning process of teachers, some teachers were actively involved in shaping (parts of) the external domain. In the TDT reported by Rock and Wilson (2005), the study and reflection of the support materials resulted in a request by the teachers for additional expertise, reflecting a change in the external domain. The change sequence illustrating this change can be summarized as follows:

Teachers studied the materials offered (EN-PERS-EXT), reflected on them (RE-EXT-PERS) and decided that they needed scientific experts to better understand their design task (EN-PERS-EXT). 
In the TDT studied by Voogt et al. (2005), teachers were actively involved in the design of a web environment that was meant to facilitate the discussions in the TDT and the exchange of curriculum materials developed by the teachers.

Teachers and facilitators jointly decided on the characteristics of the website (RE-EXT-PERS), one element was a password protected part, another way was an agreement about the teachers' contributions to the discussion and the sharing of designed lessons. These ideas were realized by the facilitators (EN-PERS-EXT), resulting in a change of the external domain (CH-EXT).

Another example of change of the external domain was found in the TDT studied by George and Lubben (2002). The teams modified and added curriculum goals to the national syllabus, because they were not able to design meaningful context-based science lessons with the objectives presented in the syllabus. The experience not only changed the external domain, but also resulted in a change in the personal domain, which is reflected by the following change sequence:

Through the discussions in the TDT (RE-EXT-PERS) many teams decided that they needed to make modifications to the curriculum objectives (EN-PERS-EXT) which resulted in selfconfidence (CH-PERS) to adopt the (preferred) context-to-objective approach.

In later stages of the design, the teachers in the George and Lubben (2002) TDT searched for additional information (on the web, in the library etc.) next to the information provided by the facilitator to use in their science lessons. Teachers felt comfortable in searching for materials themselves, because of a change in the personal domain: Through 
their participation in the TDT, teachers had gained self-confidence, as summarized in the following change sequence.

Teachers extended the external domain during the workshop in looking for other sources than those provided by the national syllabus or the materials from the facilitator (EN-PERS-EXT). This change happened because of the self-confidence gained through their participation in the TDT (CH-PERS).

In the TDT Voogt et al. (2005) studied, teachers used a website to share and discuss lessons. In this TDT, teachers jointly discussed the pedagogical ideas and framework for ICT-enhanced science lessons, but developed and implemented their own lessons. Although the website was appreciated by the teachers, it also caused feelings of uncertainty for some: One teacher did not find it easy to put his lesson on paper, although he reported learning from the lesson plans of other teachers. Another teacher was not sure about the quality of his lesson and suggested first having lesson plans approved by experts before sharing them with others. This example illustrates that the means offered in the external domain do not always facilitate reflection and enactment processes for all teachers in the TDT.

An increase in self-confidence and pedagogical content knowledge during curriculum design was also found in the study of Rock and Wilson (2005). The materials offered in the external domain offered the possibility to read and discuss professional literature and to discuss and plan new approaches with colleagues, which caused a change in the personal domain. In the study by Fernandez (2005), teachers acquired a deeper understanding of subject matter content (a change in the personal domain) when 
reflecting on how to teach their students. However, their limited understanding of subject matter content also hindered them in making sound design decisions. It was only during lesson implementation (see later) that these teachers became fully aware of their lack of understanding of subject matter content. Deketelaere and Kelchtermans (1996) found that the intense discussions and reflections in the TDT resulted in teachers' enhanced awareness of their own norms and values, yielding an altered, broader view on what 'good teaching' and being a 'good teacher' means; this indicates a change in the personal domain. Deketelaere and Kelchtermans (1996) also report an increase in teacher job satisfaction.

As argued above, teacher design activities are considered a part of the domain of practice. Because teachers in all TDTs designed curriculum materials, it is not surprising that changes in the domain of practice were found in all the studies. However, the processes that caused the change were not always described.

Shkedi (1996) studied a TDT that redesigned an existing curriculum for religious education. In his study, he found that discussion of and reflection on the existing curriculum guided the redesign, as is summarized in the following change sequence:

Teachers of the TDT jointly reflected on dilemmas that were present in the existing curriculum materials (RE-EXT-PERS). The discussion was guided by their beliefs about the content of the curriculum, and their beliefs about the impact on students. Some teachers disagreed with the opinions, attitudes and conceptions articulated in the curriculum. Based on their reflections the 
teachers decided to change a number of student activities in the student workbook (EN-PERSPRAC), resulting in a change in the domain of practice (CH-PRAC).

Similarly, the discussion in the TDT studied by Baildon and Damico (2008) about the redesign of a research unit of an Asian studies course resulted in the redesign of the tool that students could use during the unit:

Teachers studied (EN-PERS-EXT) the Critical Web Reader (a tool to guide research) and this triggered a discussion about the linear process of research suggested in the Critical Web Reader and how they and their students are reading and processing texts (RE-EXT-PERS). This discussion resulted in one of the team members offering to refine the Critical Web Reader to prepare for student use (EN-PERS-PRAC). Her changes were then adopted by the team (CHPRAC).

In the same study, a change sequence resulting in changes in the personal domain and the domain of practice during curriculum design is reported; this can be summarized as follows:

The teachers in the TDT experienced uncertainty about changes to the unit and their teaching that using the Critical Web Reader (a tool to guide research) would require (RE-PRAC-PERS), which triggered an extensive discussion about what research means, resulting in a broader view on research and the use of new terminology (research became inquiry - which was considered more process oriented and student-centered) (CH-PERS); this new terminology found its way into the curriculum handouts for students created by the team (EN-PERS-PRAC), resulting in changed practice (CH-PRAC). 
Not all teachers reacted in the same way to the discussions in their TDT. The TDT studied by George and Lubben (2002) was divided into small sub-teams. Each sub-team designed context-based science lessons, which were then discussed in the overall TDT. A major point of discussion focused on which criteria to use for selecting contexts for the science lessons. The discussions in the TDT helped some teachers (those who saw themselves as 'curriculum contributors') to change their criteria, but other teachers were less influenced by the discussions in the team (the 'curriculum implementers') and kept their original ideas.

In one study (Schneider \& Pickett, 2006), teachers with different professional backgrounds (engineers and science educators) participated in a collaborative design effort. Differences in professional culture and language hampered the collaboration during the enactment of the design. This finding is contrary to the experiences of the TDT studied by Deketelaere and Kelchtermans (1996), where teachers experienced the different professional backgrounds (technical/vocational teachers and general subject teachers) as complementary to each other. Fernandez (2005) noticed that the teachers participating in the TDT did adapt the goal of their lesson during curriculum design, which reflects a change in the domain of practice. However, the reason for the change was that teachers themselves did not understand the subject matter content very well, and anticipated problems in realizing the core lesson goals.

\subsection{Domain changes and change sequences during curriculum implementation}


During the curriculum implementation phase, the designed curriculum materials were used in the classroom. Implementation of the curriculum materials designed by the TDT was only carried out in seven of the nine studies (not in Shkedi, 1996; George \& Lubben, 2002). During curriculum implementation, changes were found in the personal domain, the domain of practice and the domain of consequences. The domain of practice during curriculum implementation differs from the domain of practice during curriculum design. Specifically, while teacher design activities characterize the domain of practice during curriculum design, the use of the designed materials in the classroom characterizes the domain of practice during curriculum implementation.

In the study by Baildon and Damico (2008), the teachers observed that the Critical Web Reader (a tool to guide research) helped students to better understand their research topic, resulting in different student outcomes. This outcome also triggered the teachers to rethink the nature of subject matter knowledge in social studies, resulting in a change in the personal domain. The change sequences that illustrate these processes can be summarized as follows:

Through the changed practice (use of the Critical Web Reader) (CH-PRAC) students did not focus on what they know, but on how they know - they were able to provide evidence for the claims they made, which resulted in teachers' observation that student outcomes had changed (RE-PRACCONS). This led to a change in the domain of consequences (CH-CONS), which triggered teachers to re-think subject matter knowledge in social studies (RE-CONS-PERS) themselves, resulting in a change in the personal domain (CH-PERS). 
Teachers believed that there were more compelling ways for students to present their research findings than the traditional research paper (that was requested by the school). They designed a project handout (EN-PERS-PRAC) that helped students to use different formats for presenting their results (CH-PRAC). Teachers were satisfied and excited about the results (CH-PRACCONS). One of the teachers expressed that these new ways of presenting results changed his way of viewing a student paper (RE-PRAC-PERS), resulting in a different view of the teacher about knowledge (CH-PERS).

\begin{abstract}
Already during lesson design, it became clear that the teachers in the TDT of Fernandez (2005) had limited subject matter content knowledge in mathematics, but that they were initially not aware of their limitations. Their incomplete knowledge of mathematics became apparent during curriculum implementation, and resulted in a change in the domain of consequences. The reflection on this consequence resulted in a change in their practice. The following change sequences illustrate what happened.
\end{abstract}

One of the teachers who had volunteered to teach the designed lesson realized during her teaching that she did not completely understand the mathematical concept (fractions) and was not able to guide the planned discussion with the students (EN-PERS-PRAC). This experience made the teacher feel bad about her teaching practice (RE-PRAC-PERS). In reflecting on this event the TDT decided to facilitate the assignment for the students (EN-PERS-PRAC).

In another part of the lesson the teacher realized (EN-PERS-PRAC) that students could carry out the task (to equally share an object) without understanding the underlying mathematical concept (fractions) (CH-CONS). The reflection on this event in the TDT fostered teachers' mathematical thinking (RE-PRAC-PERS). Because of the experience the teachers discussed how to prevent this situation (RE-PRAC-PERS) and they realized that students should not have rulers when studying fractions (CH-PRAC). 
Finally, the teachers became aware that their limited knowledge of mathematics hindered them during lesson execution. They realized that they needed to work on their subject matter knowledge with the help of external experts in order to achieve a change in the personal domain.

Because the teachers in the TDT studied by Rock and Wilson (2005) had acquired an increased understanding of pedagogical content knowledge during the collaborative design of the lessons, teachers demonstrated an increased use of subject matter related vocabulary, used manipulatives during math instruction, and applied differentiated instruction in their lessons; together, this resulted in a change in the domain of practice. These changes in teaching practice were visible in student experiences. The teachers observed that the instructional changes paid off. They were achieving their goal, which was to challenge their students.

Schneider and Pickett (2006) do not write much about the implementation of the designed curriculum as such. However, they report that the curriculum was experienced very differently by the two collaborating groups. The engineers experienced the curriculum to be substantially different from their previous practice (a large change of the domain of practice); while the science educators found the changes very limited (a minimal change in the domain of practice). Voogt et al. (2005) and Parchmann et al. (2006) found that teachers taught using the newly designed curriculum materials, but they do not report whether teachers themselves experienced those sessions as a change of their 
practice. The teachers in the TDT of Deketelaere and Kelchtermans (1996) used the curriculum materials, but they did not experience this as a change of their practice. Data about student experiences with the new curricula showed that students were satisfied (Voogt et al., 2005) and motivated (Parchmann et al., 2006), which provided evidence for a change in the domain of consequences. However, the articles do not reveal whether these results collected by the research team were discussed in the TDTs, and if so, whether they had an influence on one of the other domains.

\subsection{Indications of professional growth}

According to Clarke and Hollingsworth (2002), teacher professional growth is present in the form of long lasting change, as opposed to what they refer to as teacher change, which is the short-term change that comes as the immediate result of a professional development experience. Occurrences of teacher change (changes in the 'teacher-related domains') and the change sequences that caused the change found in the studies about TDTs have been presented in the previous sections. In this section, we present indications of teacher professional growth, which were found in the studies and were attributed to teacher participation in TDTs. The findings presented in this section are limited to indications of professional growth (as opposed to evidence of professional growth), because the studies did not systematically investigate long-lasting change. 
The experience of collaborative curriculum development was a new professional practice for most teachers participating in a TDT. Although in some of the studies teachers expressed a wish to continue with this new practice, only in one study (Deketelaere and Kelchtermans, 1996) did some of the teachers actually get involved in a TDT in their own school. As a result of their involvement in the TDT reported by Deketelaere and Kelchtermans (1996), these teachers were considered competent in curriculum design and were therefore asked to play a core role in curriculum design at the school level. We see this as an indication of long-lasting change and therefore qualify it as professional growth in the domain of practice.

Changed instructional practices after the TDT intervention was found in the study by Voogt et al. (2005). In this study, teachers in the TDT claimed to use the learner-centered approach which was developed and practiced in the TDT in $25-50 \%$ of the lessons, six months after the TDT experience. This is an indication of long-lasting change and therefore an indication of professional growth. The teachers in the TDT of Rock and Wilson (2005) demonstrated a different instructional approach and better use of subject matter vocabulary immediately after the intervention. Data collection at a later moment in time would be needed to be sure these changes are indeed long-lasting and can qualify as an indication of professional growth.

The extent to which the TDTs influenced long-lasting changes in the personal domain is not explicitly reported. One may expect that reported increases in pedagogical content knowledge (Rock and Wilson, 2005) and self-confidence (George and Lubben, 2002; 
Rock and Wilson, 2005) have a long-lasting influence on a person and therefore may indicate professional growth. The same holds for the finding of Deketelaere and Kelchtermans (1996) that teachers developed a broader view of what 'good teaching' and 'being a good teacher' means. Long-lasting changes in the domain of consequences were not reported in the studies.

\subsection{The influence of environmental factors on the TDTs}

Environmental factors may hinder or facilitate the work in the TDTs and therefore influence teacher learning. The studies reported a few environmental factors, which are briefly summarized below.

In some TDTs (George and Lubben, 2002; Baildon and Damico, 2008), it was felt that the environment influenced the design of the curriculum. In the TDT of George and Lubben (2002), teachers always kept in mind the examination requirements they were expected to meet in the higher grades, and this limited them in changing their practice. Also, in the study of Baildon and Damico (2008), teachers felt that they needed to comply with the common assessment practices in other parts of the school curriculum. They decided to satisfy both the new curriculum and the current school practice.

Teachers reflected on the requirements for students in their further studies and what that meant for the kind of products/reports students needed to make as part of the module (ENV). To accommodate these requirements, but at the same time not compromising the new curriculum they 
decided to extend the Critical Web Reader and made additional hand-outs (EN-PERS-PRAC). Students were required to write a traditional report and to present their findings using other formats (CH-PRAC).

Teachers in the study of George and Lubben (2002) did not have much professional contact with colleagues, because of a conflict with their employer. For this reason, they welcomed the collaboration in the TDT, which positively influenced the work of the TDT.

Rock and Wilson (2005) explicitly mentioned that external funding and partnership with the university facilitated the work of the TDT: it was easy to involve experts from the university; to hire substitute teachers during lesson design; to pay modest stipends to the teachers for the reports they had to deliver and for copying professional literature. On the contrary, teachers in the TDT studied by Deketelaere and Kelchtermans (1996) experienced a lack of support from their schools. Deketelaere and Kelchtermans (1996) also reported that physically moving away from their daily environment (their schools) helped teachers to develop a more de-contextualized way of thinking and therefore facilitated the work in the TDT.

In the TDT studied by Voogt et al., the idea to use a website for communication among the participants of the TDT and the external facilitator appeared problematic in practice. Due to the poor technical infrastructure, participants found the use of the website timeconsuming, and showed that it hindered the TDT activities (e.g. it took some of the teachers hours to upload their lessons to the website). 


\section{Conclusion and discussion}

This study was based on an analysis of key publications found through a systematic search of the literature on teacher design teams. The studies were based on TDTs operating in six different countries and in different subject matter domains (science, math, social studies, vocational education, and religious education). The purpose of the study was to identify processes in TDTs that contribute to teacher learning.

We began by enumerating characteristics of professional development arrangements which aim to improve or change classroom practice. The findings from this study show that the TDTs that were analyzed in this study complied with most of these characteristics. Due to the nature of TDTs, collaboration with peers is a given. In addition, most TDTs were stretched over time (except George and Lubben, 2002). Confrontation with actual classroom practice happened in seven of the nine TDTs, where the designed materials were implemented in practice. Attention for implementation also implied that follow-up support was realized. Particularly during the design phase, the TDTs paid explicit attention to subject matter understanding, often facilitated by external reading or an external facilitator. In four of the nine TDTs, exemplary materials were used to provide teachers with an image of the change that was intended. One might argue that the TDTs did not comply with the characteristic 'coherence with own and students' goals', since the goals aimed for in the TDTs were often not determined by the teachers, but by the external initiators of the TDT. 
The Interconnected Model of Professional Growth was used to trace learning trajectories in teachers. The studies we analyzed mainly described teacher change as a result of the collaborative work in the TDTs. Only a few indications of long-lasting change (which Clarke and Hollingsworth consider professional growth) were found.

The studies we analyzed showed that the stimuli and support offered in the external domain were crucial in directing the learning paths of teachers. Existing or exemplary curriculum materials were used to help the team define the goals and the design task. A lack of direction resulted in negative outcomes, as was the case in the study of Fernandez (2005). In this study, we defined two arenas of teacher practice: design activities during collaborative curriculum design; and the classroom during curriculum implementation. Teacher changes were found in both arenas. Reflection and enactment during collaborative design activities had an impact on job satisfaction and on teacher selfconfidence. Contrary to Guskey (1986), who argues that changes in beliefs only take place after classroom implementation, we found instances in TDTs that active involvement in collaborative curriculum design helped teachers to change their beliefs, particularly concerning their perception of 'good teaching' and 'being a good teacher'. During classroom implementation, teachers were able to show how they changed their classroom practice using the pedagogical content knowledge they had developed during the design activities. Student outcomes (an aspect of the domain of consequences) not only motivated teachers, but also resulted in reflections on outcomes, leading to improved classroom practice. Changed student outcomes also made teachers reflect on their 
subject, resulting in a changed vision of their subject. One important finding of our study is that TDTs which focus on the design of curriculum materials only, mainly contribute to teacher learning in the personal domain and the domain of practice; while in TDTs which also implemented the created materials, all three 'teacher-related domains' are addressed. Few environmental factors were reported that influenced the work of the TDTs. Resources that did not work properly and a lack of support from the school hindered the work in the TDTs. Teachers who were facilitated during their involvement in the TDTs found these facilities helpful for their work in the TDTs. External assessment requirements limited design activities, but teachers also found creative solutions in how to deal with these requirements while not compromising the new curriculum.

This study has its limitations. Only a few articles met the requirements for studying processes in teacher design teams and all articles had a qualitative study design. Inferences made in qualitative studies, the articles that were analyzed as well as this particular study, are easily influenced by the lens of the researcher. For this reason we deliberately discussed the results of the cross-case analysis of this study in the research team. In addition, the studies that were reported could represent a biased example of reality, as positive findings are more easily reported than negative results. Yet, we believe that we have demonstrated the potential teacher design teams have for teacher learning. Based on the findings from this study we have the following recommendations for teacher learning in TDTs:

- TDTs that aim to improve student learning should not only focus on collaborative curriculum design, but also on curriculum implementation as part of the TDT. Only 
teachers' experience with the designed curriculum materials in classroom practice provide feedback about the impact on students (cf. Guskey, 2000; Cochran-Smith, 2005).

- TDTs are an important means for teachers to develop professional interactions with peers and experts. Such professional interactions broaden teachers' perspectives (cf. Bell \& Gilbert, 1996) and are crucial for the leadership that is required from teachers in curriculum implementation (cf Riel \& Becker, 2008; Drent \& Meelissen, 2008).

- The findings of this study point to the importance of appropriate stimuli and support, preferably by an external facilitator, to guide teacher learning in TDTs, so as to prevent negative results of professional learning in teams.

- At the start of a TDT, clarity among team members about the goals and the design task (cf. Handelzalts, 2009) is crucial. In the initial phase of TDTs existing or exemplary curriculum materials can serve as concrete artifacts to help teams acquire a clearer picture of what is expected (cf. Van den Akker, 1988; Davis \& Krajcik, 2005;).

In addition, more research on the composition of the teams, the nature of the design task, the role of the external facilitator and the interactions in TDTs is needed to better understand how design teams can contribute to professional learning.

In this study, we used the Interconnected Model of Professional Growth (Clarke \& Hollingsworth, 2002) as an analytical tool to analyze teacher learning in TDTs. The model helped us to identify the processes underlying teacher learning. Until now, this model was mainly used to describe the learning of individual teachers. However, this study also shows that it is possible to use the model for identifying learning patterns that 
occur in professional development arrangements. One might argue that the model falls short in situating the interaction between the participants which occurs during collaborative design. From the perspective of the individual teacher, these interaction processes could be perceived as elements of the external domain. From the perspective of the team, the interaction reflects the reflection and enactment processes that foster the learning of individuals and the team. Although individual learning no doubt occurred in the studies reported, we particularly focused on team learning that happened in the TDTs. Clarke and Hollingsworth (2002) explicitly mention that the domain of practice refers to all professional experimentation, but also admit that the model is mainly used to track teacher changes in classroom practice. We have demonstrated that the model can also be applied to another aspect of teacher professional practice, namely collaborative curriculum design and implementation. Recent views on teacher learning (Putnam \& Borko, 2000; Borko, 2004) emphasize the importance of teacher professional communities for teacher learning. This study marks a first step toward identifying how learning processes are encouraged and knowledge is constructed in a particular type of professional community, teacher design teams.

\section{The studies}

Baildon, M. \& Damico, J. (2008). Negotiating epistemological challenges in thinking and practice: A case study of a literacy and inquiry tool as a mediator of professional conversation. Teaching and Teacher Education, 24, 1645-1657. 
Fernandez, C. (2005). Lesson Study: A Means for Elementary Teachers to Develop the Knowledge of Mathematics Needed for Reform-Minded Teaching? Mathematical Thinking and Leaning, 7, 265-289.

George, J.M. \& Lubben, F. (2002). Facilitating teachers' professional growth through their involvement in creating context-based materials in science. International Journal of Educational development, 22, 659-672.

Deketelaere, A. \& Kelchtermans, G. (1996). Collaborative curriculum development: an encounter of different professional knowledge systems. Teachers and Teaching: theory and practice, 2, 71-85.

Parchmann, I., Gräsel, P. I., Baer, A., Nentwig, P., Demuth, R., Ralle, B. (2006). Chemie im Kontext - A symbiotic implementation of a context-based teaching and learning approach. International Journal of Science Education, 28, 1041-1062.

Rock, T.C. \& Wilson, C. (2005). Improving teaching through lesson study. Teacher Education Quarterly, 32, 1, 77-92.

Schneider, R. \& Pickett, M. (2006). Bridging engineering and science teaching: a collaborative effort to design instruction for college students. School Science and Mathematics, 106 (6), 259-266.

Shkedi, A., (1996). School-based workshops for teacher participation in curriculum development. Journal of Curriculum Studies, 28, 699-711.

Voogt, J., Almekinders, M., Van den Akker, J., and Moonen, B. (2005). A blended inservice arrangement for classroom technology integration: impacts on teachers and students. Computers in Human Behavior, 21(3), 523-539. 


\section{References}

Ball, D., \& Cohen, D. (1996). Reform by the book: What is - or might be - the role of curriculum materials in teacher learning and instructional reform? Educational Researcher, 25(9), 6-8, 14.

Bell, B., \& Gilbert, J. (1996). Teacher Development: A Model from Science Education. London: Falmer Press.

Ben-Peretz, M. (1990). The teacher-curriculum encounter. Albany: State University of New York Press.

Borko, H. (2004). Professional development and teacher learning: mapping the terrain. Educational Researcher, 33, 3-15.

Bransford, J. D., Brown, A. L., \& Cocking, R. R. (Eds.). (2000). How people learn: Brain, mind, experience, and school (expanded ed.). Washington, DC: National Academy Press.

Clandinin, J., \& Connelly, F (1992). Teacher as curriculum maker. In P. Jackson (Ed.), Handbook of research on curriculum (pp. 363-401). New York: Macmillan

Clarke D. \& Hollingsworth, H. (2002). Elaborating a model of teacher professional growth. Teaching and Teacher Education, 18, 947-967.

Cobb, P. (1994). Where is the mind? Constructivist and sociocultural perspectives on mathematical development. Educational Researcher, 23, 13-19.

Cochran-Smith, M. (2005). Studying teacher education: What we know and need to know. Journal of Teacher Education, 56, 4, 301-306 
Davis, E.A., \& Krajcik, J.S. (2005). Designing educative curriculum materials to promote teacher learning. Educational Researcher, 34, 3-14.

Drent, M. \& Meelissen, M. (2008). Which factors obstruct or stimulate teacher educators to use ICT innovatively? Computers \& Education, 51(1), 187-199.

Elmore, R. F., \& Burney, D. (1999). Investing in teacher learning. In L. DarlingHammond, \& G. Sykes (Eds.), Teaching as the learning profession (pp. 236-291). San Francisco: Jossey-Bass.

Garet, M.S., Porter, A.C., Desimone, L., Birman, B.F., \& Yoon, K.S. (2001). What makes professional development effective? Results from a national sample of teachers. American Educational Research Journal, 38, 4, 915-945.

Greeno, J.G. (1998). The situativity of knowing, learning, and research. American Psychologist, 53, 1, 5-26.

Guskey, T.R. (1986). Staff development and the process of teacher change. Educational Researcher, 15, 5, 5-12.

Guskey, T.R. (2000). Evaluating Professional Development. Thousand Oaks, CA: Corwin Press.

Gustafson, K., \& Branch, R. M. (1997). Revisioning models of instructional development. Educational Technology Research and Development, 45(3), 73-89.

Handelzalts, A. (2009). Collaborative curriculum development in teacher design teams. Doctoral Thesis, University of Twente, Enschede.

Joyce, B., \& Showers, B. (1995). Student achievement through staff development: Fundamentals of school renewal (2nd ed.). White Plains, NY: Longman. 
Little, J. W. (2002). Locating learning in teachers' communities of practice: Opening up problems of analysis in records of everyday practice. Teaching and Teacher Education, 18, 917-946.

Loucks-Horsley, S., Hewson, P. W., Love, N., \& Stiles, K. E. (1998). Designing professional development for teachers of science and mathematics. California: Corwin Press.

Parke, H.M., \& Coble, C.R. (1997). Teachers designing curriculum as professional development: A model for transformational science teaching. Journal of Research in Science Teaching, 34(8), 773-789.

Penuel, W.R, Fishman, B.J., Yamaguchi, R., \& Gallagher, L.P. (2007). What makes professional development effective? Strategies that foster curriculum implementation. American Educational Research Journal, 44(4), 921-958.

Putnam, R. P., \& Borko, H. (2000). What do new views of knowledge and thinking have to say about research on teacher learning? Educational Researcher, 29(1), 1-15.

Riel, M., \& Becker, H. J. (2008). Characteristics of teacher leaders for Information and Communication Technology. In J. Voogt \& G. Knezek (Eds.). International handbook of information technology in primary and secondary education (pp. 397-417). New York: Springer.

Schön, D.A. (1987). Educating the reflective practitioner: Towards a new design for teaching and learning in the professions. San Francisco, CA: Jossey-Bass.

Simmie, G. M. 2007. Teacher design teams (TDTs) - Building capacity for innovation, learning and curriculum implementation in the continuing professional development of in-career teachers, Irish Educational Studies 26, no. 2: 163-76. 
Snyder, J., Bolin, F. \& Zumwalt, K. (1992). Curriculum implementation. In P. Jackson (Ed.), Handbook of research on curriculum (pp. 402-435). New York: Macmillan.

Taba, H. (1962). Curriculum development: Theory and practice. New York: Harcourt, Brace \& World.

Van den Akker, J. (1988). The teacher as learner in curriculum implementation. Journal of Curriculum Studies, 20(1), 47-55.

Voogt, J.M. (2010). A blended in-service arrangement for supporting science teachers in technology integration. Journal of Technology in Teacher Education, 18, 1, 83-109.

Author et al. (under review) [details removed for peer review]

Whitcomb, J., Borko, H., \& Liston, D. (2009). Growing talent: Professional development models and practices. Journal of Teacher Education, 60(3), 207-212.

Yin, R.K. (2003) Case study research: Design and methods. $3^{\text {rd }}$ Edition. Thousand Oaks: Sage. 
Table 1 Characteristics of the Teacher Design Teams and instruments used for data collection in the studies

\begin{tabular}{|c|c|c|c|c|c|c|c|}
\hline Studies & Design task & Main focus of the study & Team composition & Duration & $\begin{array}{l}\text { Educationa } \\
\text { I level }\end{array}$ & Instruments & Country \\
\hline Shkedi, 1996 & $\begin{array}{l}\text { Redesign of a student } \\
\text { workbook for religious } \\
\text { (moral) education }\end{array}$ & $\begin{array}{l}\text { Teacher participation in } \\
\text { curriculum development }\end{array}$ & $\begin{array}{l}7 \text { teachers from the same } \\
\text { secondary school }+1 \text { external } \\
\text { facilitator }\end{array}$ & 6 months & $\begin{array}{l}\text { Secondary } \\
\text { education }\end{array}$ & $\begin{array}{l}\text { Recorded group } \\
\text { discussions, } \\
\text { analysis of products }\end{array}$ & USA \\
\hline $\begin{array}{l}\text { George \& } \\
\text { Lubben, } 2002\end{array}$ & $\begin{array}{l}\text { Designing context- } \\
\text { based science lessons }\end{array}$ & $\begin{array}{l}\text { Teacher professional } \\
\text { development }\end{array}$ & $\begin{array}{l}10 \text { teachers from different } \\
\text { secondary schools }+1 \\
\text { workshop leader }\end{array}$ & $\begin{array}{l}2 \text { workshops, } \\
\text { each } 4 \text { days } \\
\text { long }\end{array}$ & $\begin{array}{l}\text { Secondary } \\
\text { education }\end{array}$ & $\begin{array}{l}\text { Interviews, } \\
\text { questionnaire, } \\
\text { recorded group } \\
\text { discussions, analysis } \\
\text { of products }\end{array}$ & $\begin{array}{l}\text { Trinidad } \\
\text { and Tobago }\end{array}$ \\
\hline $\begin{array}{l}\text { Parchmann et } \\
\text { al., } 2006\end{array}$ & $\begin{array}{l}\text { Designing context- } \\
\text { based chemistry } \\
\text { modules }\end{array}$ & $\begin{array}{l}\text { Teacher participation in } \\
\text { curriculum } \\
\text { implementation }\end{array}$ & $\begin{array}{l}\text { In each state: Teams of teachers } \\
\text { and science educators of } 8-12 \\
\text { teachers; each team was chaired } \\
\text { by a science educator and a } \\
\text { teacher }\end{array}$ & 2 years & $\begin{array}{l}\text { Secondary } \\
\text { education }\end{array}$ & $\begin{array}{l}\text { Interviews, } \\
\text { questionnaires, some } \\
\text { analysis results of } \\
\text { design products }\end{array}$ & Germany \\
\hline $\begin{array}{l}\text { Rock \& } \\
\text { Wilson, } 2005\end{array}$ & $\begin{array}{l}\text { Design of new } \\
\text { instructional approaches } \\
\text { for math and literacy }\end{array}$ & $\begin{array}{l}\text { Teacher professional } \\
\text { development }\end{array}$ & $\begin{array}{l}3 \text { teachers (math team); } 3 \\
\text { teachers ( literacy team) from } \\
\text { the same primary school }+2 \\
\text { facilitators (one from the same }\end{array}$ & 4 months & $\begin{array}{l}\text { Primary } \\
\text { education }\end{array}$ & $\begin{array}{l}\text { Teachers' self- } \\
\text { reports, interviews, } \\
\text { field notes of } \\
\text { sessions, class } \\
\text { observations }\end{array}$ & USA \\
\hline
\end{tabular}




\begin{tabular}{|c|c|c|c|c|c|c|c|}
\hline & & & primary school) & & & & \\
\hline $\begin{array}{l}\text { Fernandez, } \\
2005\end{array}$ & $\begin{array}{l}\text { Design of new } \\
\text { instructional approaches } \\
\text { for math }\end{array}$ & $\begin{array}{l}\text { Teacher professional } \\
\text { development }\end{array}$ & 4 primary school teachers & 3 months $(*)$ & $\begin{array}{l}\text { Primary } \\
\text { education }\end{array}$ & $\begin{array}{l}\text { Field notes, } \\
\text { videotapes of group } \\
\text { discussions, } \\
\text { document analysis } \\
\text { of lesson plans, } \\
\text { recorded lessons }\end{array}$ & USA \\
\hline $\begin{array}{l}\text { Voogt et al., } \\
2005-2^{\text {nd }} \\
\text { study }\end{array}$ & $\begin{array}{l}\text { Design of ICT enhanced } \\
\text { science lesson materials }\end{array}$ & $\begin{array}{l}\text { Teacher professional } \\
\text { development }\end{array}$ & $\begin{array}{l}8 \text { teachers from different } \\
\text { secondary schools }+4 \text { external } \\
\text { experts }\end{array}$ & 15 months & $\begin{array}{l}\text { Secondary } \\
\text { education }\end{array}$ & $\begin{array}{l}\text { Interviews, class } \\
\text { observations }\end{array}$ & $\begin{array}{l}\text { Russian } \\
\text { Federation }\end{array}$ \\
\hline $\begin{array}{l}\text { Deketelaere } \\
\& \\
\text { Kelchtermans } \\
, 1996\end{array}$ & $\begin{array}{l}\text { Design of curriculum } \\
\text { modules for technical } \\
\text { and vocational } \\
\text { education }\end{array}$ & $\begin{array}{l}\text { Teacher participation in } \\
\text { curriculum development } \\
\text { and } \\
\text { Teacher professional } \\
\text { development }\end{array}$ & $\begin{array}{l}18 \text { teachers from different } \\
\text { schools }\end{array}$ & 2 years & $\begin{array}{l}\text { Secondary } \\
\text { education }\end{array}$ & $\begin{array}{l}\text { Questionnaires for } \\
\text { teachers afterwards, } \\
\text { minutes of meetings, } \\
\text { researcher's diary }\end{array}$ & Belgium \\
\hline $\begin{array}{l}\text { Baildon \& } \\
\text { Damico, } \\
2008\end{array}$ & $\begin{array}{l}\text { Redesign of a module } \\
\text { integrated Asian studies } \\
\text { curriculum }\end{array}$ & $\begin{array}{l}\text { Teacher professional } \\
\text { development }\end{array}$ & $\begin{array}{l}6 \text { teachers (3 English and } 3 \\
\text { social studies teachers) from the } \\
\text { same secondary school }\end{array}$ & Unknown & $\begin{array}{l}\text { Secondary } \\
\text { education }\end{array}$ & $\begin{array}{l}\text { Interviews, } \\
\text { minutes of meetings, } \\
\text { analysis of product }\end{array}$ & Singapore \\
\hline Schneider \& & Design of a design- & Teacher participation in & 2 science educators and 2 & 1 year & Higher & Field notes of group & USA \\
\hline
\end{tabular}




\begin{tabular}{|l|l|l|l|l|l|l|l|l|l}
\hline Pickett, 2006 & based core engineering & curriculum development & engineers & education & discussions and of & & class observations, \\
& course for engineers and & & & document analysis \\
science teachers. & & & & \\
\hline
\end{tabular}

* The TDT operated during a longer period (unknown) but the article reports about one complete Lesson Study cycle 
Table 2: Overview of changes in the domains

\begin{tabular}{|c|c|c|c|c|}
\hline & $\begin{array}{l}\text { External } \\
\text { domain }\end{array}$ & Personal & Practice & Consequences \\
\hline Shkedi & & & Design & \\
\hline George \& Lubben & Design & Design & Design & \\
\hline Parchmann et al & & & $\begin{array}{c}\text { Design/ } \\
\text { Implementation }\end{array}$ & Implementation \\
\hline Rock \& Wilson & Design & Design & $\begin{array}{c}\text { Design/ } \\
\text { Implementation }\end{array}$ & Implementation \\
\hline Fernandez & & Implementation & $\begin{array}{c}\text { Design/ } \\
\text { Implementation }\end{array}$ & Implementation \\
\hline Voogt et al & Design & Design & $\begin{array}{c}\text { Design/ } \\
\text { Implementation }\end{array}$ & Implementation \\
\hline $\begin{array}{l}\text { Deketelaere \& } \\
\text { Kelchtermans } \\
\end{array}$ & & Design & $\begin{array}{c}\text { Design/ } \\
\text { Implementation }\end{array}$ & \\
\hline Baildon \& Damico & & $\begin{array}{c}\text { Design/ } \\
\text { implementation }\end{array}$ & Design & Implementation \\
\hline Schneider \& Pickett & & & $\begin{array}{c}\text { Design/ } \\
\text { Implementation }\end{array}$ & \\
\hline
\end{tabular}


Supplementary Material
Click here to download Supplementary Material: Appendix A_TDT_revised.doc

Supplementary Material
Click here to download Supplementary Material: Appendix A_TDT_revised.doc 